\title{
PENGARUH DISTRIBUSI MAKANAN, BEBAN GANDA DAN PENGAMBILAN KEPUTUSAN TERHADAP ANEMIA DALAM KEHAMILAN DI WILAYAH KERJA PUSKESMAS RUMBIO JAYA KABUPATEN KAMPAR
}

\author{
Juraida Roito Harahap, SKM, M.Kes* \\ *Dosen Jurusan Kebidanan Poltekkes Kemenkes Riau
}

\begin{abstract}
The anemia accident in the pregnant mothers at Kampar District was 56.32\%. Of Health Centers in 26 subdistricts, Kampar District, the great number of anemia accidents was at Rumbio Jaya Health Center (64.8\%). In 2010, anemia accidents in the pregnant mothers who visited Rumbio Jaya Health Center were $63.61 \%$. The prevalence of nutrition anemia in the pregnant mothers high the anemia accidents in Riau Province was 48\%. This research aimed to analyze the influence of the gender inequalities in family (food distribution, multiple burden, and decision-making in pregnancy) and mother characteristics (age, number of children, and spacing of pregnancy) on anemia in pregnancy in the working area of Rumbio Jaya Health Center. The type of the research was explanatory research. This study was conducted in the working area of Rumbio Jaya Health Center, Kampar District from December 2010 to August 2011. The population of this study were 372 pregnant mothers in March 2011, and 79 of them were selected to be the sample for this study through simple random sampling method. The result of research by using multiple logistic regression tests showed that there were the influence between food distribution and multiple burden on the anemia in pregnancy. Meanwhile, mother's age, number of child, spacing of pregnancy and decision making in pregnancy did not have any influence on the anemia in pregnancy. The variable which had the biggest influence on the anemia in pregnancy was food distribution with $\mathrm{OR}=4,338$.It is recommended in the policy making at Kampar District Health Office should formulate a gender based work program such as the health promotion program about the reproduction health and nutrition for the pregnant mothers in order to prevention of anemia in pregnant mothers.
\end{abstract}

Keywords: Gender Inequalities, Anemia, Pregnant Mothers

\section{PENDAHULUAN}

Menurut World Health

Organization (WHO), 40\% kematian ibu di negara berkembang berkaitan dengan anemia pada kehamilan dan kebanyakan anemia ini disebabkan oleh defisiensi besi. WHO melaporkan bahwa prevalensi ibu hamil yang mengalami defisiensi besi sekitar 35-75\%. Angka ini meningkat seiring dengan pertambahan usia kehamilan. Anemia defisiensi zat besi merupakan masalah gizi yang paling lazim di dunia dan menjangkiti lebih dari 600 juta manusia. Perkiraan 
prevalensi anemia secara global anak balita sekitar $43 \%$, anak usia sekolah 37\%, lelaki dewasa hanya $18 \%$, wanita tidak hamil 35\% dan wanita hamil 55\%. (Rukiyah dan Yulianti, 2010).

Pengumpulan data nasional

pada Survei Kesehatan Rumah Tangga (SKRT) tahun 1992, mencatat bahwa 63,5\% perempuan hamil menderita anemia. Angka ini menurun pada Survei Demografi Kesehatan Indonesia (SDKI) tahun 1995, menjadi 50,5\% dan menjadi $40,1 \%$ pada tahun 2001 (Depkes,2007). Hasil riset kesehatan daerah di Indonesia tahun 2010 persentase ibu hamil yang mengkonsumsi protein dibawah kebutuhan minimal sebesar 49,5\%. Ibu hamil yang mengkonsumsi energi dibawah kebutuhan minimal sebesar 44,4\% (Badan penelitian dan pengembangan kesehatan, 2010).

Berdasarkan data kesehatan di Propinsi Riau tahun 2009, ditemukan anemia gizi pada ibu hamil sebesar 48\% (Dinkes Propinsi Riau, 2009). Kejadian anemia pada ibu hamil di Kabupaten Kampar tahun 2009 sebesar 56,32\%, dari 26 Puskesmas yang tersebar di 26 Kecamatan ditemukan angka anemia terbanyak di Puskesmas Rumbio Jayasebesar 64,8\% (Dinkes Kab. Kampar, 2009). Dari catatan kunjungan ibu hamil ke Puskesmas Rumbio Jaya tahun 2010 ditemukan anemia sebesar 63,61\%. Dari data diatas terlihat masih tingginya kejadian anemia pada ibu hamil, hal ini menunjukkan keadaan gizi ibu hamil yang kurang baik. Kurangnya konsumsi makanan bergizi merupakan faktor yang menyebabkan rendahnya gizi ibu sekitar 51\% pada tahun 1990. Untuk tersebut. Oleh sebab itu upaya pencegahan dan penanggulangan anemia gizi merupakan salah satu prioritas program gizi di Indonesia.

Anemia pada kehamilan dapat mengakibatkan efek buruk baik pada ibu hamil itu sendiri maupun pada bayi yang dilahirkannya. Anemia meningkatkan resiko mendapatkan bayi dengan berat badan lahir rendah (BBLR). Hasil penelitian menunjukkan bahwa antara 42,5\%$56 \%$ kematian perinatal terdiri dari bayi BBLR. Bayi dengan berat lahir kurang dari 2500 gram mempunyai resiko kematian 5-9 kali lebih tinggi dibandingkan bayi yang beratnya 2500-2999 gram. (Prawirohardjo, 2002).

Angka kematian ibu (AKI) merupakan salah satu indikator kesehatan ibu yang masih cukup tinggi di Indonesia bila di bandingkan dengan AKI di negara ASEAN lainnya. Menurut SDKI tahun 2007, AKI di Indonesia yaitu 228 per 100.000 kelahiran hidup. Adapun faktor penyebab langsung kematian ibu adalah perdarahan $35,63 \%$, pre eklamsia dan eklamsia 20,12\%, infeksi 20,7\% dan komplikasi abortus 20,84\%. Perdarahan merupakan faktor terbesar penyebab tingginya AKI. Salah satu faktor resiko utama terjadinya perdarahan adalah anemia. Pada penelitian evidence base epidemiologi, anemia defisiensi zat besi ibu hamil di Indonesia yang diteliti oleh Ridwan Amiruddin menunjukkan bahwa 70\% dari angka kematian ibu adalah ibu hamil yang anemia dan $19,7 \%$ ibu hamil yang non anemia (Ridwan, 2004). 
Kebijakan Departemen Kesehatan (Depkes) dalam upaya mempercepat penurunan AKI mengacu kepada intervensi strategis yaitu empat pilar safe motherhood yang salah satu pilarnya adalah kehamilan dengan tujuan agar setiap ibu hamil dapat melalui kehamilan dan persalinannya dengan selamat. Hal ini sesuai dengan paradigma baru Depkes bahwa pembangunan kesehatan lebih ditekankan pada upaya promotif dan preventif. Upaya lain untuk menurunkan AKI adalah Gerakan Sayang Ibu (GSI). GSI adalah gerakan yang dilaksanakan oleh masyarakat bekerja sama dengan pemerintah untuk meningkatkan kualitas hidup perempuan melalui berbagai kegiatan antara lain penyadaran kaum pria agar memberikan hak reproduksi kepada perempuan. Tidak terpenuhinya hak kesehatan reproduksi pada perempuan disebabkan rendahnya status perempuan dimasyarakat (Depkes, 2007).

Hak reproduksi perempuan berkaitan erat dengan masalah kemiskinan. Hal ini dapat dilihat dari jumlah perempuan yang hidup dalam kemiskinan lebih banyak dibandingkan laki-laki. Karena terbatasnya akses perempuan terhadap sumber-sumber ekonomi. Rendahnya pendapatan mengakibatkan perempuan tidak memeriksakan kehamilannya. Keluarga juga tidak dapat membeli makanan yang dibutuhkan ibu hamil. Karena anggapan bahwa kehamilan merupakan peristiwa alamiah sehingga harus ditanggung resikonya oleh perempuan.
Penelitian yang dilakukan di kelurahan Jatirawamangun oleh kelompok studi wanita FISIP UI (1990) menemukan bahwa 47,1\% ibu yang bekerja mengatakan tugas utamanya adalah ibu rumah tangga dan 51\% dari ibu ini tidak mempunyai pembantu rumah tangga. Hasil penelitian tersebut menunjukkan banyak perempuan yang tidak mengetahui hak reproduksinya sendiri, perempuan biasa dengan berbagai kewajiban di rumah tangga.Perempuan juga menanggung dua jenis pekerjaan yang berat yaitu pekerjaan reproduktif di rumah tangga dan pekerjaan produktif mencari nafkah, sehingga jam istirahat perempuan lebih pendek dari laki-laki. Perempuan mempunyai beban ganda sehingga hal ini membuat perempuan lebih sering mengalami tingkat kesehatan yang buruk dan komplikasi kehamilan. Beberapa penelitian menunjukkan bahwa karakteristik ibu mempunyai hubungan yang signifikan dan beresiko terhadap anemia dalam kehamilan. Hasil penelitian Ridwan tentang studi kasus kontrol faktor biomedis terhadap anemia di Puskesmas Bantimurung tahun 2004 membuktikan bahwa kejadian anemia ibu hamil lebih tinggi pada umur kurang dari 20 tahun dan lebih dari 35 tahun.

Hasil wawancara pada studi awal dengan masyarakat di Kabupaten Kampar menunjukkan adanya beberapa perilaku yang menyangkut kesehatan pada ibu hamil seperti ibu biasanya makan paling akhir setelah bapak dan orang tua, sehingga ibu memperoleh 
alokasi makanan yang tidak mencukupi, terutama untuk ibu hamil. Tentunya hal ini sangat berpengaruh terhadap konsumsi makanan ibu dan berpotensi untuk terjadinya anemia. Seharusnya makanan ibu hamil diutamakan dalam keluarga karena ibu hamil yang sehat akan melahirkan bayi yang sehat.

Peneliti juga melakukan wawancara dengan5 orang ibu hamil yang berkunjung ke Puskesmas Rumbio Jaya ternyata banyak ibu yang membantu mencari nafkah dengan bekerja di perkebunan sawit sebagai buruh harian walaupun sedang hamil disamping tetap mengerjakan pekerjaan rumah tangga. pengambilan keputusan tentang kehamilan ibu masih ditentukan oleh suami. Ibu hanya mengikuti kemauan suami saja. Berdasarkan beberapa masalah diatas, perlu dilakukan penelitian pengaruh ketimpangan gender dalam keluarga dan karakteristik ibu terhadap anemia dalam kehamilan.

\section{TUJUAN PENELITIAN}

Untuk menganalisispengaruh ketimpangan gender dalam keluarga (distribusi makanan, beban ganda, pengambilan keputusan terhadap kehamilan)dan karakteristik ibu (umur, jumlah anak, jarak kehamilan) terhadap anemia dalam kehamilan di wilayah kerja Puskesmas Rumbio Jaya Kabupaten Kampar Tahun 2011.

\section{MANFAAT PENELITIAN}

Hasil penelitian ini dapat digunakan sebagai bahan dalam merumuskan program kerja berperspektif gender dalam upaya pencegahan anemia pada ibu hamil. Selain itu, hasil penelitian ini juga dapat digunakan sebagai bahan pertimbangan dalam memberikan pendidikan kesehatan pada ibu hamil tentang pencegahan anemia melalui kegiatan KIE, promosi atau kampanye.

\section{KERANGKA KONSEP PENELITIAN}

Berdasarkan tujuan penelitian dan landasan teori, maka kerangka konsep penelitian ini dapat digambarkan sebagai berikut:

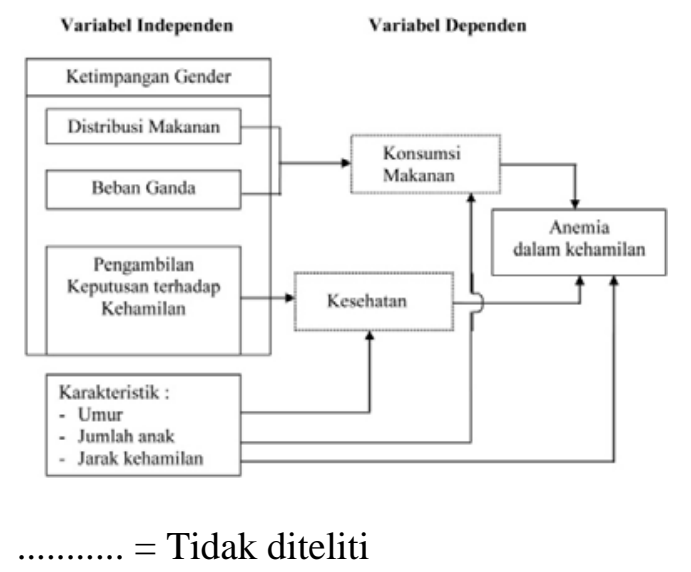

\section{Gambar Kerangka Konsep Penelitian}

Variabel independen dalam penelitian ini adalahketimpangan gender yang terdiri dari distribusi makanan, beban ganda, pengambilan keputusan terhadap kehamilan dan karakteristik ibu yaitu umur, jumlah anak, jarak kehamilan. Variabel dependen adalah anemia dalam kehamilan.

Ketimpangan gender tampak dari tradisi di masyarakat bahwa ibu selalu makan bagian terakhir, akibatnya alokasi makanan untuk ibu tidak memadai, distribusi dan kualitas makanan untuk ibu hamil 
bernilai rendah, sehingga ibu hamil dapat mengalami anemia. Ketimpangan dalam melaksanakan peran reproduktif, produktif dan sosial, menyebabkan ibu mempunyai beban ganda. Akibatnya ibu membutuhkan energi yang lebih besar. Ibu membutuhkan konsumsi gizi yang baik, apabila tidak terpenuhi maka dapat terjadi anemia pada ibu hamil.Ketidakmampuan ibu dalam mengambil keputusan yang berkaitan dengan kehamilannya, menyebabkan kesehatan ibu menjadi buruk seperti jarak kehamilan yang pendek dan jumlah anak yang banyak. Ketidaksiapan tubuh ibu menerima kehamilan karena pemulihan faktor hormonal dan kekurangan nutrisi dapat mengakibatkan anemia.

\section{HASIL DAN PEMBAHASAN}

\section{Anemia dalam Kehamilan}

Dari hasil analisis didapat sebagian besar ibu hamil di wilayah kerja Puskesmas Rumbio Jaya Kabupaten Kampar Provinsi Riau Tahun 2011 mengalami anemia dalam kehamilan (64,6\%). Keadaan ini menunjukkan angka yang lebih tinggi dari angka anemia di Kabupaten Kampar sebesar 56,32\%. Angka yang didapat pada penelitian ini juga lebih tinggi dari kejadian anemia di Provinsi Riau (48\%) dan SDKI tahun 2001 sebesar 40,1\%.

Hal ini sesuai dengan teori yang diungkapkan oleh Manuaba (1998) yangmengatakan bahwa setiap wanita hamil akan mengalami anemia dalam kehamilan karena terjadinya penurunan kadar $\mathrm{Hb}$ dalam darah. Anemia dalam kehamilan memberikan pengaruh kurang baik bagi ibu dan janin. Adapun bahaya anemia selama kehamilan dapat terjadi abortus, partus prematur, gangguan pertumbuhan janin dalam rahim, mudah terjadi infeksi, berat badan lahir rendah dan perdarahan antepartum.

Upaya pencegahan dan penanggulangan anemia menurut Depkes RI (1996) dilakukan dengan intervensi terhadap penyebab langsung, penyebab tidak langsung maupun sebab mendasar. Upaya yang dilakukan pada primary prevention adalah memberikan makanan bergizi pada ibu hamil melalui perbaikan gizi, melakukan penyuluhan tentang anemia pada ibu hamil melalui kegiatan komunikasi, informasi dan edukasi (KIE), promosi atau kampanye tentang anemia kepada masyarakat luas. Pengobatan penyakit infeksi dan tersedianya tablet tambah darah dalam jumlah yang sesuai. Pada secondary prevention dilakukan intervensi yang berbasis pangan melalui peningkatan konsumsi zat gizi dari makanan. Sedangkan upaya tertier prevention dilakukan intervensi yang berbasis non pangan.

Sedangkan untuk mengatasi penyebab tidak langsung, perlu dilakukan usaha meningkatkan perhatian dan kasih sayang didalam keluarga terhadap wanita, terutama ibu hamil dengan cara penyediaan makanan yang sesuai dengan kebutuhan ibu hamil, mendahulukan ibu hamil pada waktu makan, memperhatikan agar pekerjaan fisik sesuai dengan kondisi ibu hamil dan merawat ibu hamil yang sakit agar cepat sembuh. Dalam jangka panjang, penanggulangan anemia 
dapat dilakukan secara tuntas bila penyebab mendasar terjadinya anemia ditanggulangi. Intervensi yang dapat dilakukan adalah meningkatkan pendidikan, memperbaiki upah karyawan wanita, meningkatkan status wanita di masyarakat.

Secara umum strategi operasional penanggulangan anemia diarahkan pada empat kegiatan yaitu KIE, kegiatan suplementasi, kegiatan fortifikasi dan kegiatan lain yang mendukung kemauan masyarakat dalam menanggulangi anemia secara mandiri. Kegiatan KIE diarahkan untuk mencari dukungan sosial (social support) yang bertujuan untuk meningkatkan status wanita didalam keluarga, terutama agar keluarga lebih menghargai dan memperhatikan ibu hamil. Pendekatan pimpinan (advokacy) melalui KIE yang ditujukan kepada sasaran sekunder yang mempunyai kemampuan untuk melakukan kebijakan dalam rangka menciptakan lingkungan yang lebih mendukung dan mempercepat pelaksanaan program. KIE dalam pemberdayaan yaitu KIE yang bertujuan untuk menumbuhkan kesadaran keluarga tentang anemia, pangan dan gizi serta dapat melakukan tindakan penanggulangan anemia secara mandiri.

\section{Pengaruh Distribusi makanan, Beban Ganda dan Pengambilan Keputusan terhadap Anemia Kehamilan}

\section{a. Distribusi makanan}

Hasil penelitian menunjukkan bahwa, anemia lebih banyak ditemukan pada ibu yang distribusi makanannya kurang baik (62,7\%) dibandingkan dengan ibu yang distribusi makanannya baik (37,3\%). Secara statistik uji chi squaremenunjukkan bahwa ada hubungan yang bermakna antara pembagian makanan yang tidak sesuai dengan kebutuhan ibu hamil dalam keluarga (distribusi makanan) dengan anemia dalam kehamilan $(p=0,039)$. Hasil analisis multivariat menunjukkan ada pengaruh antara pembagian makanan yang tidak memenuhi kebutuhan ibu hamil dalam keluarga dengan anemia dalam kehamilan.

Penyebab terjadinya anemia adalah faktor makanan.Pembagian makanan yang tepat kepada setiap orang dalam keluarga adalah penting untuk mencapai gizi baik. Makanan harus dibagikan untuk memenuhi kebutuhan gizi seimbang setiap orang dalam keluarga. Menurut Simatauw (2001), nilai-nilai sosial budayayang menganggap perempuan sebagai masyarakat nomor dua menyebabkan timbulnya perbedaan perlakuan dari orang tua sejak kecil dalam hal penyedian makanan untuk anak perempuan.

Secara tradisional dalam masyarakat ada aturan dimana ayah mempunyai prioritas utama atas jumlah dan jenis makanan tertentu dalam keluarga, anggota keluarga lainnya menempati urutan prioritas berikutnya dan yang paling umum mendapat prioritas terbawah adalah ibu. Apabila hal yang demikian itu masih dianut dengan kuat oleh keluarga maka dapat saja timbul distribusi konsumsi makanan yang tidak baik diantara anggota keluarga.

Berdasarkan uji regresi logistik, diketahui bahwa variabel 
yang paling dominan pengaruhnya terhadap anemia dalam kehamilan adalah distribusi makanan $\mathrm{OR}=4,338$ artinya pembagian makanan yang tidak memenuhi kebutuhan ibu hamil dalam keluarga mempunyai peluang 4,338 kali mengalami anemia dibandingkan dengan ibu hamil yangpembagian makanannya terpenuhi.

Dalam masyarakat ada aturan yang menentukan kuantitas, kualitas dan jenis makanan yang seharusnya dikonsumsi oleh anggota-anggota suatu keluarga sesuai dengan kedudukan, usia, jenis kelamin dan situasi tertentu. Misalnya ibu hamil pantang makanan tertentu, ayah yang bekerja sebagai pencari nafkah berhak mendapatkan jumlah makanan yang lebih banyak dari pada anggota keluarga lainnya, anak laki-laki diberi makan lebih dahulu dari pada anak perempuan.

Dari hasil pengumpulan data secara kualitatif ditemukan adanya perlakuan tidak adil dalam pembagian makanan di keluarga yaitu memberikan prioritas makanan untuk ayah terutama bagian lauk pauk dari makanan seperti ikan, ayam, daging dan lain-lain dengan alasan ayah mencari uang. Hal ini sering terjadi baikjika keluarga makan bersama ataupun tidak makan bersama. Setiap hari makanan untuk ayah selalu dipisahkan dari makanan anggota yang lainnya. Hal ini sejalan dengan penelitian kualitatif yang dilakukan Taslim (1988) pada orang betawi yang memperlihatkan bahwa ayah mendapatkan jumlah makanan yang paling banyak, anak perempuan mendapatkan makanan lebih sedikit dari pada anak laki-laki dengan alasan anak perempuan harus menjaga bentuk tubuhnya, dan ibulah yang paling sedikit mengkonsumsi makanan.

Demikian juga dari hasil wawancara mendalam yang dilakukan terhadap tiga orang informan ditemukan bahwa ibu hamil kebanyakan tidak merasa berhak atas kebutuhan akan makanan. Ibu menganggap kehamilan adalah proses alamiah sehingga tidak merasa perlu untuk memprioritaskan makanan untuk dirinya, ibu cukup makan dengan porsi yang sama sebelum hamil. Hal ini tentu berpengaruh kepada mereka sebagai perempuan yang sedang membutuhkan perhatian, zat makanan dan perlindungan. Tidak terlindunginya para ibu hamil dari aturan, pantangan atau larangan yang diajarkan oleh lingkungannya menyebabkan ibu hamil cenderung hanya menerima semuanya tanpa memikirkan akibat bagi kesehatannya. Kepercayaan dan norma ini sering tidak diperhatikan dalam berbagai upaya promosi kesehatan, status ibu hamil masih merupakan subordinasi dari suaminya. Masyarakat dan ibu hamil sendiri menganggap kehamilan sebagai suatu proses yang biasa saja. Artinya tidak ada kepentingan yang harus dicermati dengan lebih baik ketika istri sedang hamil, padahal kehamilan adalah proses penting.

Jelaslah bahwa pencegahan anemia pada ibu hamil lebih ditekankan kepada upaya untuk membongkar berbagai praktekpraktek kesehatan yang tidak berpihak pada wanita. Maka dengan demikian penanggung jawab terjadinya anemia pada ibu hamil adalah mereka yang secara kolektif 
telah mendisain budaya yang ada yang diwariskan secara turun temurun, baik tokoh agama dan tokoh masyarakat yang ada di masyarakat.

\section{b. Beban Ganda}

Hasil uji chi square menunjukkan bahwa ada hubungan antara pekerjaan yang dilakukan ibu hamil di rumah tangga, mencari nafkah dan peran sosial dengan anemia dalam kehamilan $(p=0,000)$.Ketimpangan dalam melaksanakan peran reproduktif, produktif dan sosial, menyebabkan ibu mempunyai beban ganda. Akibatnya ibu membutuhkan energi yang lebih besar. Ibu membutuhkan konsumsi gizi yang baik, apabila tidak terpenuhi maka dapat terjadi anemia pada ibu hamil. Kesehatan ibu hamil akan terganggu jika ibu harus bekerja keras untuk mendapatkan penghasilan keluarga, disamping tetap dituntut melaksanakan pekerjaan rumah tangga.

Waktu yang dicurahkan untuk pekerjaaan rumah tangga oleh wanita di pedesaan adalah intensif dan banyak, khususnya rumah tangga dari golongan ekonomi lemah. Pekerjaan itu memerlukan banyak waktu dan energi, disebabkan oleh kurangnya fasilitas teknologi. Berbeda dengan rumah tangga lapisan atas yang mampu mengurangi beban dalam pekerjaan rumah tangga karena mempunyai alat-alat fasilitas yang lebih baik dan mempunyai biaya membayar orang untuk membantunya.

Hasil uji regresi logistik menunjukkan ada pengaruh pekerjaan yang dilakukan ibu hamil di rumah tangga, mencari nafkah dan peran sosial dengan anemia dalam kehamilan. Mendukung pendapat Sihite (2007), bahwa bias gender yang mengakibatkan beban kerja tersebut seringkali diperkuat dan disebabkan adanya pandangan atau keyakinan dimasyarakat bahwa pekerjaan yang dianggap masyarakat sebagai jenis pekerjaan perempuan, seperti pekerjaan domestik, dianggap dan dinilai lebih rendah dibandingkan dengan jenis pekerjaan yang dianggap sebagai pekerjaan lelaki, serta dikategorikan sebagai bukan produktif sehingga tidak diperhitungkan dalam statistik ekonomi negara. Hampir setengah dari istri melakukan aktivitas ekonomi disektor publik seperti karyawan, buruh, pembantu dan lainlain, untuk menutupi kekurangan pendapatan suami dalam upaya memenuhi kebutuhan rumah tangga. Keputusan istri terjun ke sektor publik ini sebagai wujud tanggung jawab mereka terhadap masa depan rumah tangga terutama anakanaknya.

Hasil penelitian ini didukung oleh penelitian kelompok studi wanita FISIP-UI (1990)yang menemukan 95\% wanita dari golongan bawah bekerja karena ingin menambah penghasilan rumah tangga. Perempuan juga harus berperan secara sosial yang mencakup kegiatan sosial dan gotong royong dalam kehidupan masyarakat, seperti perayaan, keselamatan, kesertaan dalam organisasi, kesertaan dalam kegiatan politik. Kegiatan ini tidak menghasilkan uang tetapi seringkali menyerap banyak waktu dan penting bagi pemeliharaan dan pengembangan 
aspek spiritual, kultural komunitas serta sebagai alat komunikasi.

Hasil wawancara mendalam yang dilakukan terhadap informan ditemukan bahwa mayoritas pekerjaan rumah tangga dikerjakan oleh ibu, karena menurut informan perempuan hanya cocok bekerja di rumah tangga sedangkan suami mencari nafkah. Jika istri bekerja mencari nafkah itu karena ingin mencari uang untuk menambah penghasilan sedangkan pekerjaan rumah tangga tetap menjadi tanggung jawabnya.

Hasil wawancara ini dipertegas oleh informan lain yang menyatakan jika ibu pulang dari bekerja di kebun bersama suami maka sesampai di rumah ibu mempersiapkan pekerjaan rumah tangga yang tertunda akibat ibu bekerja di kebun sedangkan bapak duduk-duduk di warung menunggu makanan selesai dimasak. Ibu menjadi kurang beristirahat dan kelelahan sehingga nafsu makan berkurang.

Peranan suami dalam kegiatan rumah tangga akan membantu menyelamatkan istri dari kelebihan peran dalam keluarga dan peran dalam masyarakat, serta akan mengurangi konflik antar keluarga. Menurut hasil penelitian Umami dan Puspitasari (2007), salah satu faktor yang memengaruhi seorang suami ikut berpartisipasi dalam pekerjaan rumah tangga adalah pandangan peran gender yang dianut suami.

Suami yang memiliki pandangan peran gender tradisional memandang bahwa laki-laki adalah sebagai penguasa utama rumah tangga yang memiliki hak-hak istimewa dan otoritas terbesar dalam keluarga sehingga kurang bersedia mengerjakan tugas rumah tangga. Suami yang memiliki pandangan peran gender modern berpendapat bahwa laki-laki dan perempuan adalah setara, karena itu suami dapat menyesuaikan diri dengan peran istri di rumah tangga dan bersedia menerima tanggung jawab yang lebih besar dalam kegiatan rumah tangga terutama pada saat istri sedang hamil.

\section{c. Pengambilan Keputusan terhadap Kehamilan}

Dari hasil penelitian ditemukan bahwa, anemia lebih banyak terjadi pada ibu dengan pengambilan keputusan terhadap kehamilan kurang baik (74,5\%) dibandingkan dengan ibu yang pengambilan keputusannya baik (25,5\%). Secara statistik uji regresi logistik pada penelitian ini tidak ada pengaruh yang bermakna antara pengambilan keputusan terhadap kehamilan dengan anemia $(p=0,622)$.

Pengambilan keputusan

terhadap kehamilan mencakup perawatan kehamilan, jumlah anak dalam keluarga dan jarak anak yang dilahirkan dalam penelitian ini menunjukkan 74,5\% kurang baik namun tidak ada pengaruh secara uji statistik disebabkan jumlah anak yang dimiliki keluarga rata-rata 1-2 orang dengan jarak kehamilan $>2$ tahun sebesar 58,8\%. Umur ibu juga berkisar antara 20-35 tahun.

Hal ini diperkuat oleh penelitian Mien Hidayat (2005), secara kualitatif menemukan bahwa sebagian bapak-bapak yang umumnya pegawai dan berusia relatif muda mengemukakan proses pembuatan keputusan terhadap kehamilan dilakukan secara 
musyawarah suami dan istri. Dalam musyawarah tersebut dikemukakan berbagai solusi pemecahan masalah kemudian si istri diberi wewenang untuk memilih salah satu solusi terbaik menurutnya, suami menopang berbagai aspek dalam pelaksanaan keputusan tersebut. Bagian lainnya menyatakan bahwa untuk kesehatan kehamilannya, mereka menyerahkan penuh kepada istrinya untuk memutuskan sendiri apa yang akan ditempuh dalam pemeliharaan kehamilannya, karena merekalah yang paling tahu mengenai masalah tersebut dan apa yang mereka butuhkan. Dengan syarat apa yang akan diputuskan itu, terlebih dulu diberitahukan kepada suami sebelum dilaksanakan.

\section{KESIMPULAN}

Berdasarkan analisis dengan uji statistik dan pembahasan dapat ditarik kesimpulan sebagai berikut:

1. Kejadian anemia pada ibu hamil di wilayah kerja Puskesmas Rumbio Jaya $(64,6 \%)$ lebih tinggi daripada kejadian anemia di Kabupaten Kampar (56,32\%).

2. Umur, jarak kehamilan, pembagian makanan yang tidak memenuhi kebutuhan ibu hamil (distribusi makanan) dan pekerjaan berlebihan yang dilakukan ibu hamildi rumah tangga, mencari nafkah dan peran sosial (beban ganda) mempunyai hubungan yang signifikan dengan kejadian anemia dalam kehamilan.

3. Ketimpangan gender yang mencakup distribusi makanan dan beban ganda pada ibu hamil dapat meningkatkan kejadian anemia dalam kehamilan.

\section{DAFTAR PUSTAKA}

Abdullah, I., 2001. Seks, Gender \& Reproduksi Kekuasaan, Yogyakarta : Tarawang Press.

Anshori, D.S., Kosasih, E., Sarimaya, F., 1997. Membincangkan Feminisme, Bandung : pustaka hidayah.

Arikunto, S., 2002. Prosedur Penelitian Suatu Pendekatan, Jakarta:Rineka Cipta.

Badan Penelitian dan Pengembangan Kesehatan, 2010. Hasil Riset Kesehatan Dasar 2010, Jakarta : Kementerian Kesehatan Republik Indonesia.

Baso, Z.A., 2000. Langkah Perempuan Menuju Tegaknya Hak-Hak Konsumen, Sulawesi Selatan: Yayasan Lembaga Konsumen.

Daulay, H., 2007. Perempuan dalam Kemelut Gender, Medan : USU Press.

Depkes.RI., 1996. Pedoman Operasional Penanggulangan Anemia Gizi di Indonesia, Jakarta : Dirjen pembinaan kesehatan masyarakat. 2003. Profil Gerakan partisipatif penyelamatan ibu hamil, menyusui \& bayi, Jakarta: MNH. , 2007. Profil Kesehatan dan Pembangunan Perempuan di Indonesia, Jakarta : WHO.

Dinkes Kab.Kampar, 2009. Profil Kesehatan Kabupaten Kampar : Kampar.

Dinkes Propinsi Riau, 2009. Profil Kesehatan Propinsi Riau. Pekanbaru.

Effendy, N., 1998. Dasar-dasar Keperawatan Kesehatan Masyarakat, Jakarta : EGC. 
Fakih, M., 1996. Analisis gender \& Transformasi Sosial, yogyakarta :Pustaka Pelajar.

Handayani, T., dan Sugiarti, 2008. Konsep dan Teknik Penelitian Gender, Malang : Universitas Muhammadiyah Malang (UMM) Press.

Hartini, T., 2006. Pengarusutamaan Gender dan Pemberdayaan Perempuan, Jurnal Perempuan. YJP. No. 50 : 77.

Herlina, N., dan Djamilus, F., 2006. Faktor Resiko kejadian Anemia pada Ibu Hamil di Wilayah Kerja Puskesmas Bogor, Bogor: Majalah pengembangan dan pemberdayaan sumberdaya manusia kesehatan, volume 2, No.2:32 - 33.

Hidayat, M., 2005. Komunikasi Pengambilan Keputusan untuk Pemeliharaan Kesehatan Reproduksi pada Ibu-ibu Rumah Tangga di Pedesaan, Bandung : Fakultas Ilmu Komunikasi UNPAD.

Kelompok Studi Wanita FISIP UI, 1990. Para Ibu yang Berperan Tunggal dan yang Berperan Ganda, Jakarta : Fakultas Ekonomi UI.

Kementerian Negara Pemberdayaan Perempuan, 2006. Kesetaraan dan Keadilan Gender bagi Organisasi Masyarakat Keagamaan, Jakarta : 74-76.

Luhulima, A. S., 2006. Pemahaman Bentuk-Bentuk Tindak Kekerasan terhadap Perempuan dan Alternatif Pemecahannya, Jakarta : Kelompok Kerja Convention Watch Pusat
Kajian Wanita Dan Gender Universitas Indonesia.

Machfoedz, I., 2005. Teknik Membuat Alat Ukur Penelitian, Jogjakarta : Fitramaya.

Manuaba, 2008. Memahami Kesehatan Reproduksi Wanita, Jakarta : Arcan.

Munthe, H. M., 2003. Hubungan Status Istri Bekerja dengan Pola Kekuasaan dalam Keluarga, Tesis, Bandung : Fakultas Sosial UNPAD.

Nasution, E. H., 2005. Strategi Penanggulangan Anemia pada Ibu Hamil di Wilayah Kerja Tujuh Puskesmas kota Medan, Tesis, Medan : FKM USU.

Notoatmodjo, S., 2005. Metodologi Penelitian Kesehatan, Jakarta: Penerbit Rineka Cipta. , 2007. Kesehatan Masyarakat Ilmu dan Seni, Jakarta : Penerbit Rineka Cipta.

Nugroho,T., dan Setiawan,A., 2010. Kesehatan Wanita, Gender \& Permasalahannya, Yogyakarta : Nuha Medika.

Prawirohardjo, S., 2002. Ilmu kebidanan, Jakarta : YBD-SP.

Puskesmas Rumbio Jaya, 2011. Laporan PWS KIA bulan Maret.

Ridwan,A., dan Wahyuddin., 2004. Studi Kasus Kontrol faktor Biomedis terhadap Kejadian Anemia Ibu Hamil di Puskesmas Bantimurung Maros, Diakses tanggal 8 Maret 2011, www.google.com.

Rochjati, P., 2003. Skrining antenatal pada ibu hamil, Surabaya : Fakultas Kedokteran UNAIR.

Rukiyah, A. Y., dan Yulianti, L., 2010. Patologi Kebidanan, 
Jakarta : CV Trans Info Media.

Sahala, S., 2001. Mainstream Gender dan Upaya Pemberdayaan Perempuan di Bidang Hukum, Jakarta : Badan Pembinaan Hukum Nasional Departemen Kehakiman dan Hak Asasi Manusia RI.

Sajogyo, P., 1983. Peranan wanita dalam perkembangan

Masyarakat desa. Jakarta : CV. Rajawali.

Salmah, Rusmiati, Maryanah, Susanti, N. N., 2006. Asuhan Kebidanan Antenatal, Jakarta : EGC.

Saryono, 2009. Metodologi Penelitian Kesehatan, Yogyakarta : Mitra Cendikia Press.

Setiono, K., Masjhur, J.S., Alisyahbana, A.,1998. Manusia, Kesehatan dan Lingkungan, Bandung : Alumni.

Setyawan, H., Asri, N.P., Endang, 1997. Pengaruh Anemia Ibu hamil Trimester III terhadap Kejadian Bayi Berat Lahir Rendah (BBLR), Prematuritas dan Intra Uterine growth Retardation (IUGR), Jurnal Epidemiologi Indonesia Volume 1 Edisi 3 : 9-15.

Sibagariang, E. E., Pusmaika, R., Rismalinda, 2010. Kesehatan Reproduksi Wanita, Jakarta: CV Trans Info Media.

Sihite, R, 2007. Perempuan, Kesetaraan, Keadilan suatu tinjauan Berwawasan Gender, Jakarta: PT Raja Grafindo Persada.

Simatauw, M., Simanjuntak, L., Kuswardono, P.T.,
2001.Gender dan pengelolaan

Sumber Daya Alam, Jogjakarta: Yayasan Pikul (Penguatan Institusi dan Kapasitas Lokal).

Soetrisno, L., 1997.Kemiskinan, Perempuan dan Pemberdayaan, Yogyakarta : Kanisius.

Sukandar, D., 2006. Makanan Tabu di Rokan Hulu, Riau, Info Kesehatan Masyarakat volume X No.2: 113-117.

Tarwoto dan Wasnidar, 2007.Anemia pada Ibu Hamil, Jakarta: Trans Info Media.

Taslim, A. 1988. Kebiasaan Makan pada Anak Balita dan kekurangan Kalori Protein, Jakarta : Jurusan Antropologi FISIP UI.

Umami, R. dan Puspitasari, N., 2007. Peran Suami selama Proses Kehamilan sampai Nifas Istri, The Indonesian Journal of Public Health, Volume 3 no. 3 : 101-107.

Wolfman, B.R., 1990. Peran Kaum Wanita, Yogyakarta Kanisius.

Yustina, I., 2005. Membangun Keluarga Berkualitas dari Perspektif Kesehatan Reproduksi, Majalah Kesehatan masyarakat, volume IX no. 1 : 57-60.

2007. Pemahaman Keluarga Tentang Kesehatan Reproduksi, Medan: Pustaka Bangsa Press.

Zaluchu,F., 2005. Faktor SosioPsikologi Masyarakat yang berhubungan dengan Anemia Ibu Hamil di Kota Tanjung Balai, Sumatera Utara, The Indonesian Journal of Public Health, Volume 1 no. 1 :11-1 